\title{
Inflammation and nitric oxide production in skeletal muscle of type 2 diabetic patients
}

\author{
S H Torres, J B De Sanctis ${ }^{1}, M$ de L Briceño ${ }^{2}$, N Hernández and \\ $\mathrm{H} \mathrm{J} \mathrm{Finol}^{3}$ \\ Institute of Experimental Medicine, Section of Muscle Adaptation (SEAM), Central University of Venezuela, Caracas, Venezuela \\ ${ }^{1}$ Institute of Immunology, Central University of Venezuela, Caracas, Venezuela \\ ${ }^{2}$ Endocrinology Service, Hospital J M Vargas, Faculty of Medicine, Central University of Venezuela, Caracas, Venezuela \\ ${ }^{3}$ Centre for Electron Microscopy, Faculty of Sciences, Central University of Venezuela, Caracas, Venezuela \\ (Requests for offprints should be addressed to S H Torres, Instituto de Medicina Experimental, Apdo. 50587 Sabana Grande, Caracas 1050-A Venezuela; \\ Email: heckers@camelot.rect.ucv.ve)
}

\begin{abstract}
An inflammatory process may be involved in nitric oxide production in skeletal muscle of type 2 diabetic patients. Nitric oxide generation in skeletal muscle was assessed in 14 non-complicated type 2 diabetic patients and in 12 healthy subjects. In samples of quadriceps femoris muscle, endothelial nitric oxide synthase (eNOS), inducible nitric oxide synthase (iNOS), nitrite, nitrate and nitrotyrosine were determined. The macrophage-specific antigen CD163, the T-cell membrane factor CD154 and tumour necrosis factor- $\alpha$ (TNF- $\alpha$ ) were also assayed. In six patients, ultrastructural analysis of muscle was performed. Nitrites and nitrates were increased in patients as compared to controls $(22 \cdot 7 \pm 4 \cdot 5$ and $32 \cdot 7 \pm 7 \cdot 0$ vs $16 \cdot 0 \pm 2 \cdot 9$ and $22.8 \pm 4.0 \mu \mathrm{mol} / \mathrm{mg}$ protein; $P<0.001$, MannWhitney U test). Endothelial NOS was similar in diabetic and control subjects $(36 \cdot 4 \pm 13 \cdot 8$ vs $36 \cdot 3 \pm 6 \cdot 8 \mathrm{ng} / \mathrm{mg}$
\end{abstract}

protein), contrasting with the significant increase of iNOS recorded in patients $(34.3 \pm 13.0$ vs $8.5 \pm 2.8 \mathrm{ng} / \mathrm{mg}$ protein, $P<0 \cdot 00002)$. Nitrotyrosine levels were higher in the patient than in the control group $(42 \cdot 1 \pm 24 \cdot 4$ vs $10 \cdot 3 \pm 2 \cdot 5 \mathrm{ng} / \mathrm{mg}$ protein, $P<0 \cdot 00002)$, as were CD163 (10-fold) and TNF- $\alpha$ (fourfold) levels. Furthermore, CD154 levels were detectable only in the patient samples $(10 \cdot 2 \pm 5 \cdot 3 \mathrm{ng} / \mathrm{mg}$ protein). By multiple-regression analysis, changes in glycated haemoglobin values could predict $96 \%$ variation in nitrotyrosine. Macrophages were present in all muscle samples analysed by electromicroscopy. The increased levels of CD163, CD154 and TNF- $\alpha$ indicate that an inflammatory process occurs in skeletal muscle of type 2 diabetic patients. This may contribute to iNOS induction, muscle damage and insulin resistance.

Journal of Endocrinology (2004) 181, 419-427

\section{Introduction}

There is growing evidence that chronic inflammation has a role in the pathogenesis of type 2 diabetes (Pickup et al. 2000, Marette 2002), but it has been shown that nitric oxide (NO) has a regulatory effect in the immune system (van der Veen 2001). However, excessive NO formation mediates non-specific tissue damage and has been found to be involved in the development of muscle insulin resistance in diet-induced obesity (Perreault \& Marette 2001).

The synthesis of NO is catalysed by at least three isoforms of nitric oxide synthase (NOS). Two of the isoforms are constitutively expressed, one in endothelial cells (eNOS) and the other in the brain (nNOS); the third one, inducible (i) NOS, is induced by inflammatory cytokines such as interleukin-1 (IL-1) or tumour necrosis factor alpha $(\mathrm{TNF}-\alpha)$ in macrophages and many other cell types (Moncada et al. 1991, Beck et al. 1999). At low concentration, NO stimulates guanylate cyclase activity, which mediates physiological vasodilatation, inhibits platelet aggregation and leukocyte adhesion, protects against cytokine-induced damage and is a major derived immunosuppressive factor for T-cell immunity (Moncada et al. 1991, van der Veen 2001). However, the activation of the inducible isoform (iNOS) through inflammatory stimulants produces $\mathrm{NO}$ in thousand-fold larger quantities, which mediate pathological processes (Beck et al. 1999). $\mathrm{NO}$ can be transformed in reaction with another free radical superoxide $\left(\mathrm{O}_{2}^{-}\right)$to form peroxynitrite $\left(\mathrm{ONOO}^{-}\right)$. This reaction between $\mathrm{NO}$ and $\mathrm{O}_{2}{ }^{-}$is extremely strong and is three times faster than the rate at which superoxide dismutase scavenges $\mathrm{O}_{2}^{-}$. Peroxynitrite can nitrate lipids and proteins. Nitration can cause protein dysfunction, but few proteins that appear nitrated in vivo have been identified; one of them is nitrotyrosine, which is a marker of peroxynitrite production (Beckman \& Koppenol 1996).

Many biochemical pathways associated with hyperglycaemia (such as glucose auto-oxidation, polyol pathways, 
eicosanoid synthesis and protein glycation) increase the production of $\mathrm{O}_{2}^{-}$(Di Mario \& Pugliese 2001, Zou et al. 2002). There are also indications that $\mathrm{O}_{2}{ }^{-}$can be produced by eNOS (Schmidt et al. 1996, Wang et al. 2000). Therefore, the simultaneous production of $\mathrm{NO}$ and $\mathrm{O}_{2}{ }^{-}$is possible.

The generation of $\mathrm{NO}$ in type 2 diabetes, mainly investigated in vascular endothelium, has been a controversial issue. The endothelial dysfunction of the disease has been associated with decrement in NO production, impaired NO-mediated, endothelium-dependent relaxation, or increased NO production accompanied by augmented neutralisation of $\mathrm{NO}$ by $\mathrm{O}_{2}^{-}$(Pieper 1998). Nitrotyrosine detection in plasma of diabetic patients (Ceriello et al 2001), together with the increased expression of NOS and $\mathrm{O}_{2}^{-}$production in human aortic endothelial cells exposed to high levels of glucose (Cosentino et al. 1997), supports the hypothesis that there is an increased production of $\mathrm{NO}$ and peroxide in diabetic patients.

The isoform nNOS has been detected in various normal human skeletal muscles at the surface membrane of the fibres and at the neuromuscular junctions. Low levels of iNOS have also been reported (Stamler \& Meissner 2001). In addition, NOS activity similar to eNOS has been demonstrated in skeletal muscle, as well as mRNA expression of iNOS and eNOS (Wang et al. 2001). In pathological conditions such as heart failure and autoimmune myopathies, the expression of iNOS in skeletal muscle is highly increased (Stamler \& Meissner 2001). iNOS expression in muscle cells was induced by the combination of IL-1 $\alpha$ - and interferon gamma (IFN- $\gamma$ ), both in vitro and in vivo (Adams et al. 2002), and by the combination of TNF- $\alpha$ and IFN- $\gamma$ in cultured skeletal muscle cells (Bedard et al. 1998).

$\mathrm{NO}$ is generated by macrophages during the process of antigen presentation to T cells (van der Veen 2001). The activated $\mathrm{T}$ helper cell $(\mathrm{Th})$ expresses co-stimulatory molecules that, together with several cytokines, including IFN- $\gamma$, induce NO production in the macrophage. One of the T-cell co-stimulatory molecules is CD40L (CD154), which is part of receptor-ligand families, including the TNF-receptor and TNF family (van der Veen 2001). CD154 is expressed on activated mature T cells, but not in resting $\mathrm{T}$ cells, and is involved in the amplification and regulation of inflammatory responses (van Kooten \& Banchereau 2000). Chronic activation of $\mathrm{T}$ cells, as reported in autoimmunity and organ rejection, is dependent upon overexpression of CD154. The elevated levels of CD154 in individuals with type 1 or 2 diabetes were considered as evidence of a proinflammatory state (Varo et al. 2003).

The aim of the present study was to analyse the production of $\mathrm{NO}$ in skeletal muscle of type 2 diabetic patients and to find out whether this process is related to inflammatory factors. Therefore, the enzymes eNOS and
iNOS, and the products of $\mathrm{NO}$ formation, $\mathrm{NO}_{2}{ }^{-}, \mathrm{NO}_{3}{ }^{-}$ and nitrotyrosine, were determined in quadriceps femoris muscle of these patients, as well as CD163, a specific antigen of human macrophages (Malm et al. 2000). The inflammatory cytokine TNF- $\alpha$, and the indicator of activated CD4 ${ }^{+}$cells, CD154 (van Kooten \& Banchereau 2000), were also determined in the muscle samples. To confirm the presence of macrophages, some muscle sections were observed with the electron microscope.

\section{Materials and Methods}

\section{Subjects}

Fourteen type 2 diabetic patients (eight men and six women), aged $46 \cdot 6 \pm 7 \cdot 5$ years, were treated with oral hypoglycaemic agents (glibenclamide, gliclazide or metformin) until blood glucose was under $13.1 \mathrm{mmol} / \mathrm{l}$. Diagnosis of type 2 diabetes was made 2 months to 13 years before the study. The studied subjects were descendants of a mixture of white Europeans, black Africans and native South American Indians. None of the subjects were hypertensive or had signs of renal or retinal complications. The control group was formed by 12 healthy volunteers (nine men and three women) of similar age $(45 \cdot 6 \pm 12 \cdot 6$ years). The body-mass index (BMI) of patients was $27 \cdot 2 \pm 5 \cdot 1$ and of control subjects $24 \cdot 3 \pm 3 \cdot 9$. The characteristics of the subjects are shown in Table 1.

\section{Muscle biopsy}

A muscle biopsy was taken from the vastus lateralis part of quadriceps muscle with a Bergström needle, under local anaesthetic and antiseptic conditions. Consent of all patients and control subjects was obtained after the muscle biopsy procedure was explained to them. The study was approved by the hospital ethics committee. Muscle samples were frozen in isopentane cooled in liquid nitrogen and kept at $-80{ }^{\circ} \mathrm{C}$ until processing. In six patients, part of the muscle sample was fixed in $3 \%$ glutaraldehyde in phosphate buffer, at $\mathrm{pH} 7 \cdot 4$ and $320 \mathrm{mOsmol}$, for ultrastructural study.

\section{Ultrastructure}

The muscle sample was postfixed in $1 \% \mathrm{OsO}_{4}$ and embedded in epon; sections were cut with a diamond knife in a Porter-Blum MT2 ultramicrotome, stained with uranyl acetate and lead citrate, and observed in a Hitachi H-500 transmission electron microscope, at an acceleration voltage of $100 \mathrm{kV}$.

\section{Assessment of NO products in muscle}

Frozen muscle samples were weighed, and the tissue was minced in a glass homogeniser with $1 \mathrm{ml}$ of buffer, 
Table 1 Type 2 diabetic patients and control subjects characteristics

\begin{tabular}{|c|c|c|c|c|c|}
\hline \multirow{3}{*}{$\operatorname{Sex}(M / F)$} & \multicolumn{2}{|l|}{ Patients } & \multicolumn{2}{|c|}{ Control subjects } & \multirow[t]{2}{*}{$P$} \\
\hline & $8 / 6$ & & $9 / 3$ & & \\
\hline & Means \pm S.D. & Range & Means \pm S.D. & Range & \\
\hline Age (years) & $46 \cdot 6 \pm 7 \cdot 5$ & $32-59$ & $45 \cdot 6 \pm 12 \cdot 6$ & $27-67$ & NS \\
\hline BMI & $27 \cdot 2 \pm 5 \cdot 1$ & $19 \cdot 11-35 \cdot 69$ & $24 \cdot 30 \pm 3 \cdot 9$ & $19 \cdot 80-26 \cdot 64$ & NS \\
\hline Glycaemia (mmol/l) & $8 \cdot 00 \pm 2 \cdot 76$ & $5 \cdot 06-13 \cdot 11$ & & & \\
\hline Glycated haemoglobin (mmol/l) & $11 \cdot 2 \pm 5 \cdot 7$ & $5 \cdot 6-23 \cdot 3$ & & & \\
\hline Diagnosis time of the disease (months) & $37 \pm 43$ & $2-156$ & & & \\
\hline
\end{tabular}

BMI: body mass index.

Tris-HCl 10 mmol/1, pH 7·5; NaCl, 150 mmol/l; EDTA, $5 \mathrm{mmol} / \mathrm{l}$; triton $\mathrm{X}-100,1 \%(\mathrm{v} / \mathrm{v}) ; 10 \mu \mathrm{g} / \mathrm{ml}$ leupeptin; $10 \mu \mathrm{g} / \mathrm{ml}$ aprotinin; and $2.5 \mathrm{~g} / \mathrm{ml}$ pepstatin A. The homogenised tissue was placed in an Eppendorf tube and centrifuged at $90 \mathrm{~g}$. The supernatant was used for the rest of the assays. Protein concentration was assessed by the BCA protein assay kit (Pierce Biochemicals, Rockfort, IL, USA).

NO levels were determined indirectly by quantification of their oxidised products of degradation, nitrates and nitrites, using nitrate reductase and the Greiss reagent (Green et al. 1982) by the method of Moshage et al. (1995). Briefly, the supernatants of homogenised tissue were diluted fourfold with distilled water and incubated with nitrate reductase from Aspergillus spp. in order to quantify the total amount of NO products (nitrites plus nitrates). In the absence of the enzyme, only nitrite concentrations are determined. After 30-min incubation at $37^{\circ} \mathrm{C}$ in the presence of the enzyme and its cofactors $\mathrm{NADPH}$ and $\mathrm{FADH}_{2}$, and further incubation for $10 \mathrm{~min}$ with sodium pyruvate and lactic dehydrogenase to degrade excess NADPH, the samples were deproteinised with zinc sulphate, and $100 \mu \mathrm{l}$ of the supernatant were mixed with $100 \mu \mathrm{l}$ of Greiss reagent (a solution containing equimolar amounts of solution A $(2.5 \%$ phosphoric acid and $10 \%$ sulphonamide) and solution B ( $0 \cdot 1 \%$ ethylendiamine)). A standard curve was obtained with sodium nitrate dissolved in water or in a pool of normal human serums. Nitrite concentration was determined at $540 \mathrm{~nm}$ by an ELISA plate reader (Labsystems Multiscan MCC/340, Pulttitte 8, Helsinki, Finland). The interassay and intra-assay coefficients of variation for the Greiss reaction were $5.6 \%$ and $3 \cdot 6 \%$ respectively.

The total amount of nitrotyrosine was determined by a standard sandwich ELISA, as described by Ye et al. (1996). All antibodies, the mouse immunoglobulin (Ig) G monoclonal antibody, for capturing the modified amino acid, the polyclonal against nitrotyrosine, and the polyclonal goat antirabbit IgG-peroxidase, were purchased from Upstate Biotechnology (Lake Placid, NY, USA). The nitrotyrosine was quantified by a standard curve with known concentrations of nitrotyrosine from chemically modified bovine serum albumin. The interassay and intra-assay coefficient of variations were $8 \%$ and $11 \%$ respectively. The sensitivity of the assay was $50 \mathrm{pg} / \mathrm{ml}$.

\section{Determination of NOS in muscle}

Determination of constitutive eNOS A quantikine kit purchased from R \& D Systems (Minneapolis MN, USA) was used to ascertain the levels of eNOS in muscle tissue according to the manufacturer's instructions. The sensitivity was $25 \mathrm{pg} / \mathrm{ml}$ under the conditions tested, using recombinant eNOS. The inter- and intra-assay variations were less than $8 \%$.

Determination of iNOS A standard sandwich ELISA was used to determine iNOS. Briefly, the monoclonal antihuman iNOS (Serotec Corporation, Kidlington, Oxford, UK) was adsorbed to the plate at a concentration of $1 \mu \mathrm{g} /$ well with PBS. The plate was then blocked with $1 \%$ bovine serum and $0.05 \%$ Tween 20 in PBS for $1 \mathrm{~h}$ at $37^{\circ} \mathrm{C}$. Then, $100 \mu \mathrm{l}$ pure or $1: 2,1: 4$ diluted (in PBS) supernatant of homogenised tissue were incubated overnight at room temperature. The plates were washed, and the secondary antibody, a polyclonal rabbit antihuman iNOS (Serotec), was incubated at a concentration of $1 \mu \mathrm{g} / \mathrm{ml}$ for $1 \mathrm{~h}$ at $37^{\circ} \mathrm{C}$. The plates were washed again and incubated with goat antirabbit IgG-peroxidase for $1 \mathrm{~h}$ at $37^{\circ} \mathrm{C}$. Finally, the plates were washed and incubated with tetramethyl benzidine and read at $492 \mathrm{~nm}$ in an ELISA reader system (Labsystem, MA, USA). Purified iNOS (by affinity column) was used to perform a standard curve. The sensitivity of the assay was $40 \mathrm{pg} / \mathrm{ml}$. No cross-reaction was observed when recombinant eNOS was used in the assay. The inter- and intra-assay variation was $12 \%$.

\section{Assessment of CD163 in muscle}

A sandwich ELISA was performed as described by Sulahian et al. (2001), with minor modifications. Briefly, monoclonal anti-CD163 (clone ED-Hu1, Serotec) was used to capture CD163, and the biotinylated 
clone RM3/1 was used to detect the molecule. The homogenised muscle samples were diluted 1:10 in distilled water prior to being added to the plates and incubated overnight. The rest of the procedure was performed as described by Sulahian et al. (2001), except that CD163 was purified from the supernatant of phormol myristate acetate (PMA)-activated monocytes by affinity chromatography using the monoclonal clone ED-Hu1, and the purified protein was used to perform the standard curve. The detection limit was 100-10000 pg of purified CD163. The specificity was confirmed by immunoprecipitation of CD163 in homogenised muscle tissue prior to the assay.

\section{Assessment of TNF-a in muscle}

TNF- $\alpha$ was assessed by a third-generation TNF- $\alpha$ quantikine assay (R \& D Systems) according to the manufacturer's instructions except that samples were diluted as suggested for serum samples and incubated for 18 instead of $3 \mathrm{~h}$. The sensitivity of the assay was $0 \cdot 5-3 \mathrm{pg} / \mathrm{ml}$.

\section{Assessment of CD154 in muscle}

CD154 levels were detected by a commercial sandwich immunoenzymatic assay purchased from Chemicon Corporation (Temécula, CA, USA). The ELISA plates were already coated with the capturing monoclonal. The samples were diluted as specified by the manufacturer in the assay buffer, and the only modification was that the samples were incubated for $18 \mathrm{~h}$ at $4{ }^{\circ} \mathrm{C}$. Quantitative analysis was performed with a standard curve. The detection limit was $1 \mathrm{ng}$ CD154 per mg of protein.

\section{Blood samples}

Glucose was assayed by an enzymatic method (Qualitest). Glycated $\mathrm{HbA}$ was determined by resin column separation (Sigma kit).

\section{Statistical analysis}

Results are expressed as mean \pm S.D. of the mean. Comparison between patients and controls was made by the Mann-Whitney U test. Correlations were made with the Pearson and Spearman tests. A stepwise multipleregression analysis (Statistica, StatSoft Inc., Tulsa, OK, USA) was performed. A value of $P<0.05$ was considered statistically significant.

\section{Results}

At the time of the muscle biopsy, blood glucose was $8.00 \pm 2.76 \mathrm{mmol} / \mathrm{l}$. In nine patients, the values of glycated haemoglobin were available $(11 \cdot 19 \pm 5 \cdot 71 \%)$. In

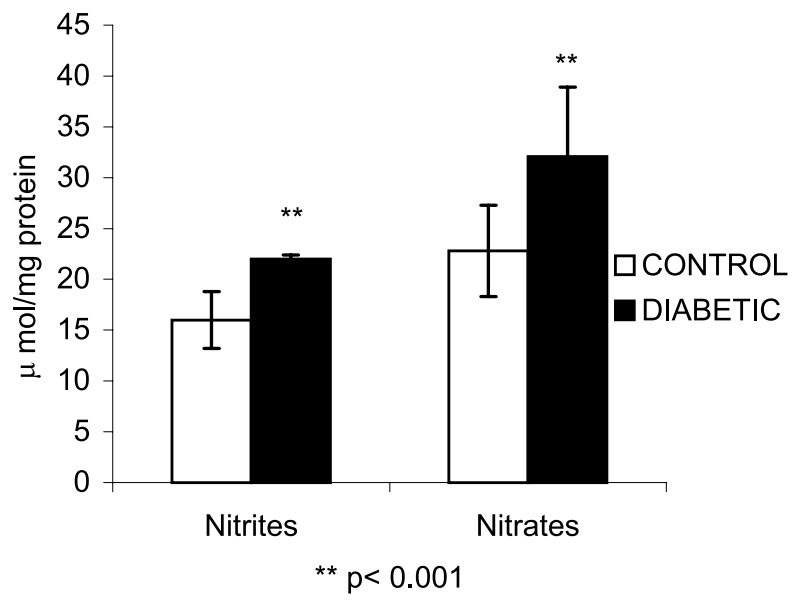

Figure 1 Levels of nitrites and nitrates in quadriceps muscle of type 2 diabetic patients (black columns) and control subjects (white columns). Mean values \pm S.D. in $\mu \mathrm{mol} / \mathrm{mg}$ protein.

diabetic patients, nitrites and nitrates in skeletal muscle were $40 \%$ higher than in control subjects $\left(\mathrm{NO}_{2}{ }^{-}\right.$ $16 \cdot 0 \pm 2.9 \mu \mathrm{mol} / \mathrm{mg}$ protein in controls vs $22 \cdot 7 \pm$ $4.5 \mu \mathrm{mol} / \mathrm{mg}$ protein in patients $(P<0.0009) ; \mathrm{NO}_{3}{ }^{-}$ $22.8 \pm 4.0 \mu \mathrm{mol} / \mathrm{mg}$ protein in controls vs $32.7 \pm$ $7 \cdot 0 \mu \mathrm{mol} / \mathrm{mg}$ protein in patients $(P<0 \cdot 0007)$ (Fig. 1)). The ratio $\mathrm{NO}_{3}{ }^{-} / \mathrm{NO}_{2}{ }^{-}$did not differ between control and diabetic subjects $(1 \cdot 43 \pm 0 \cdot 19$ and $1 \cdot 50 \pm 0 \cdot 39)$.

The eNOS level was similar in diabetic and control subjects $(36.3 \pm 6.8 \mathrm{ng} / \mathrm{mg}$ protein in controls; $36 \cdot 4 \pm 13 \cdot 8 \mathrm{ng} / \mathrm{mg}$ protein in patients), but iNOS was fourfold higher in the skeletal muscle of the diabetic group $(8 \cdot 5 \pm 2 \cdot 8 \mathrm{ng} / \mathrm{mg}$ protein in controls; $34 \cdot 3 \pm 13 \cdot 0 \mathrm{ng} / \mathrm{mg}$ protein in patients $(P<0.00002)$ (Fig. 2)). Nitrotyrosine showed a similar difference, around 300\% higher in

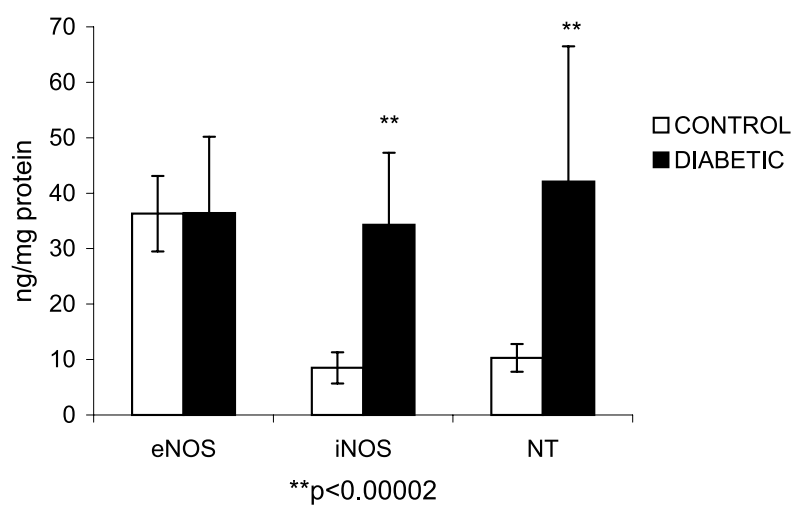

Figure 2 Levels of constitutive endothelial nitric oxide synthase (eNOS), inducible nitric oxide synthase (iNOS) and nitrotyrosine (NT) in quadriceps muscle of type 2 diabetic patients (black columns) and control subjects (white columns). Mean values \pm S.D. in $\mathrm{ng} / \mathrm{mg}$ protein. 


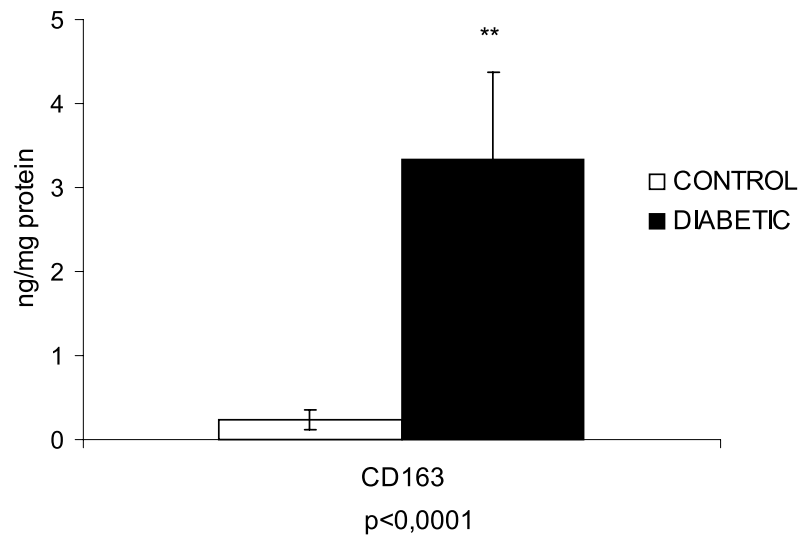

Figure 3 CD163 in quadriceps muscle of type 2 diabetic patients (black column) and control subjects (white column). Mean values \pm S.D. in $\mathrm{ng} / \mathrm{mg}$ protein.

diabetic patients (control subjects $10 \cdot 3 \pm 2 \cdot 5 \mathrm{ng} / \mathrm{mg}$ protein; diabetic patients $42 \cdot 1 \pm 24.4 \mathrm{ng} / \mathrm{mg}$ protein $(P<0 \cdot 00002)$ (Fig. 2)).

CD163 was analysed in all patients and in nine control subjects. Patients showed over 10 times more CD163 than the control subjects $(0.24 \pm 0.12 \mathrm{ng} / \mathrm{mg}$ protein in controls; $3.33 \pm 1.05 \mathrm{ng} / \mathrm{mg}$ protein in patients $(P<0 \cdot 00008)$ (Fig. 3)). TNF- $\alpha$ was $44 \cdot 8 \pm 15 \cdot 8 \mathrm{pg} / \mathrm{mg}$ protein in control subjects and $177 \cdot 6 \pm 147 \cdot 0 \mathrm{pg} / \mathrm{mg}$ protein in the patient group $(P<0 \cdot 01)$ (Fig. 4$)$ ).

CD154 was found only in homogenates of diabetic patients and was undetectable in those of the control subjects $(10 \cdot 2 \pm 5 \cdot 3 \mathrm{ng} / \mathrm{mg}$ protein as compared to undetectable; limit of the method $1 \mathrm{ng} / \mathrm{mg}$ protein), implying the presence of activated IFN- $\gamma$-producing $\mathrm{CD}^{+}$cells.

The level of iNOS and of CD163 correlated to the levels of nitrotyrosine (Fig. 5). Plasma glycated haemoglobin values showed a direct correlation to TNF- $\alpha$ (Fig. 6), nitrotyrosine and CD163 (Fig. 7).

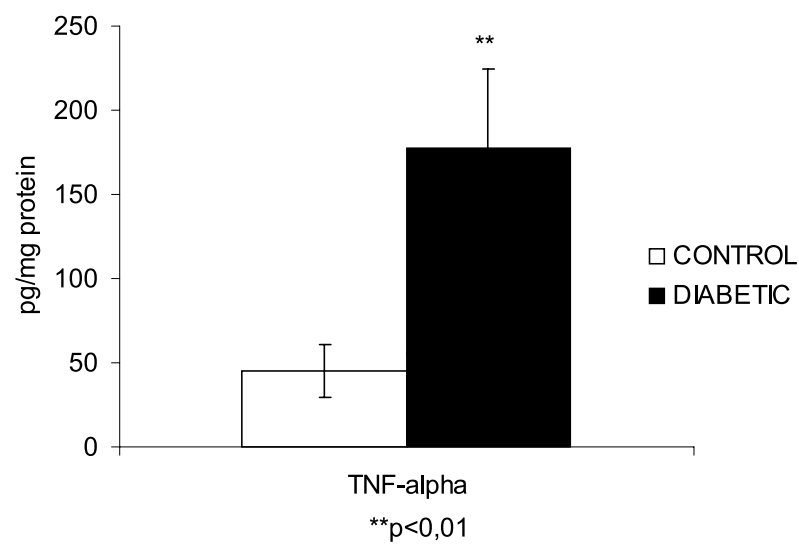

Figure 4 Tumour necrosis factor alpha (TNF-alpha) in quadriceps muscle of type 2 diabetic patients (black column) and control subjects (white column). Mean values \pm S.E.M. in $\mathrm{pg} / \mathrm{mg}$ protein.
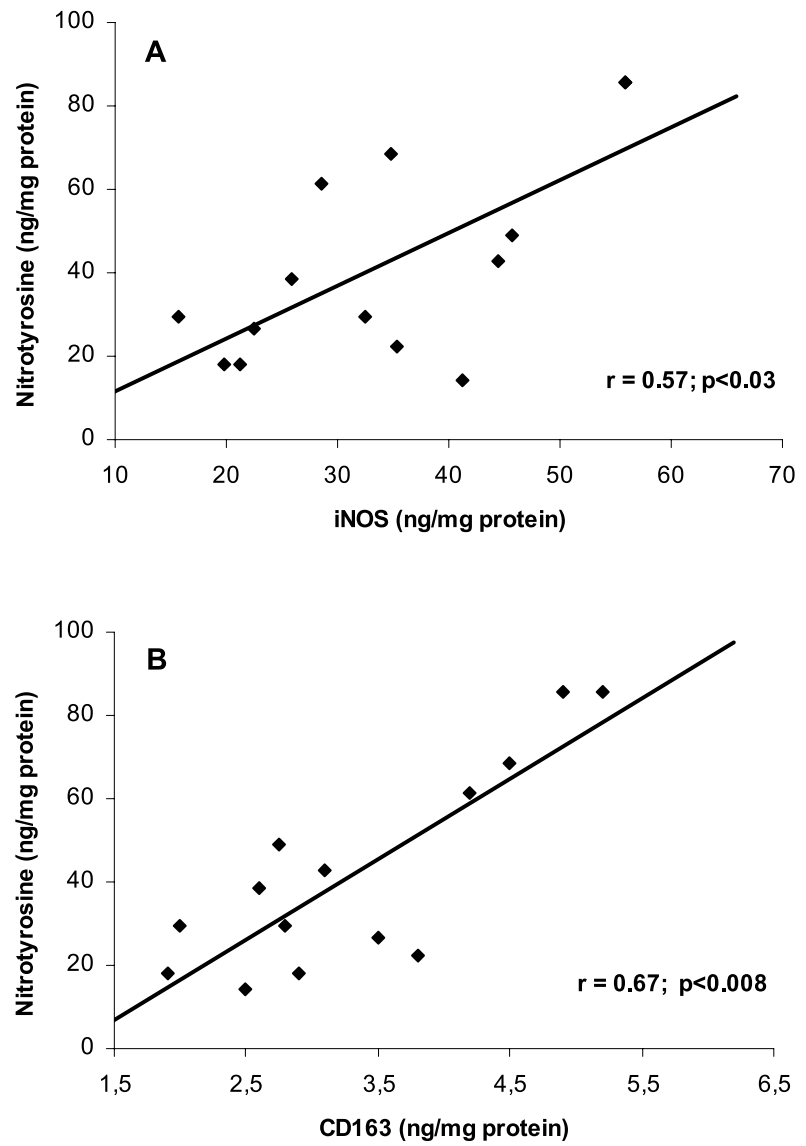

Figure 5 Correlations (Spearman) of inducible nitric oxide synthase (iNOS) (A) and CD163 (B) to nitrotyrosine.

Multiple-regression analysis showed that the variation in nitrotyrosine could be predicted from changes in glycated haemoglobin, the percentage of explained variance being $96 \%$; after adding the next step of the multivariate regression analysis, the age of the patients, the fraction of

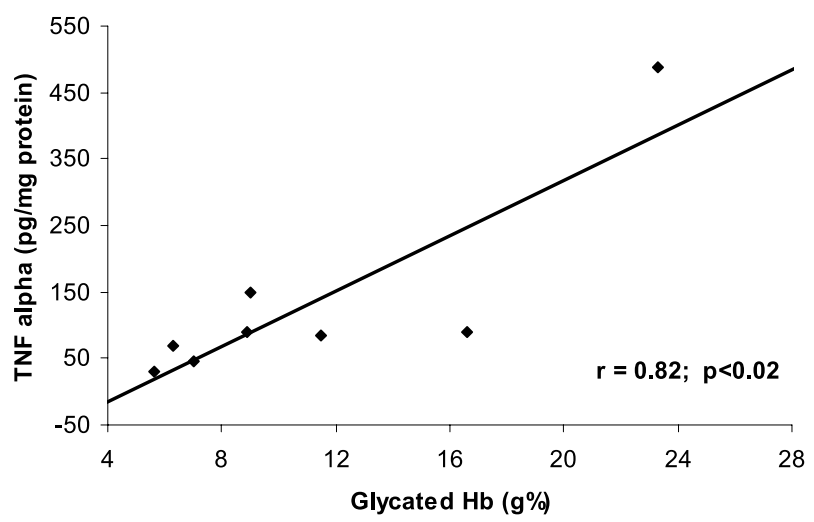

Figure 6 Correlation (Spearman) of glycated haemoglobin $(\mathrm{Hb})$ to tumour necrosis factor alpha (TNF- $\alpha$ ).

Journal of Endocrinology (2004) 181, 419-427 

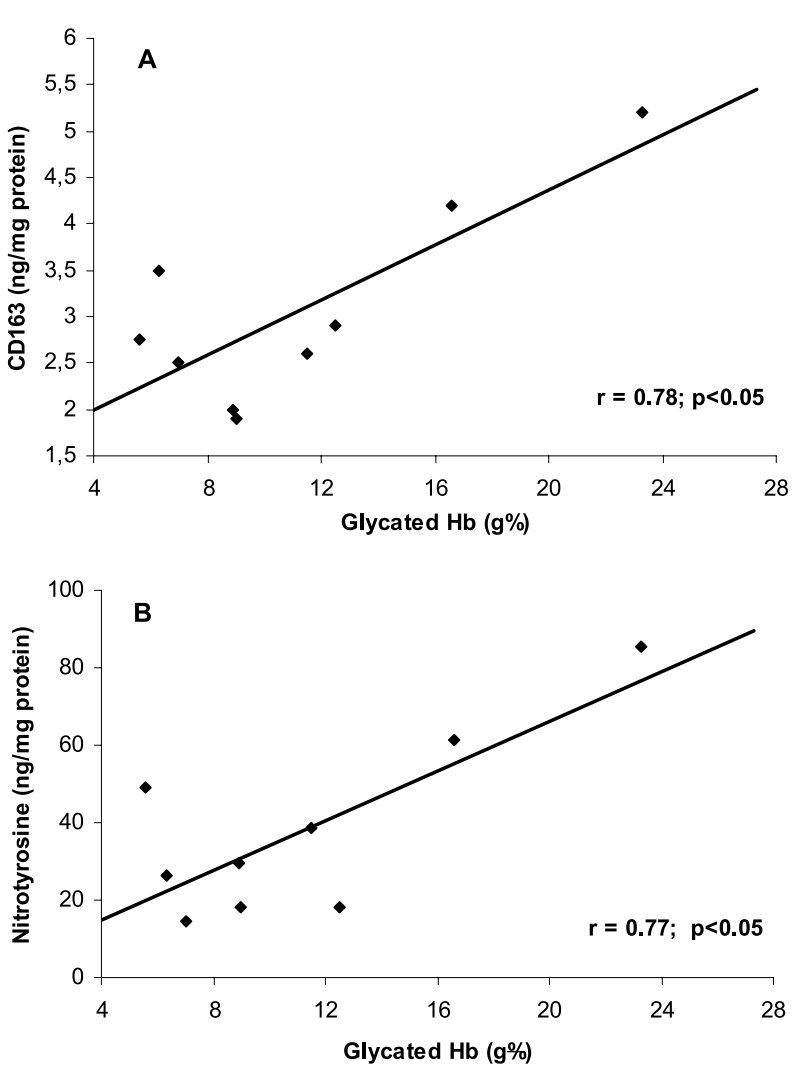

Figure 7 Correlations (Pearson) of glycated haemoglobin $(\mathrm{Hb})$ to DC163 (A) and nitrotyrosine (B).

explained variance increased to $99 \%$. The variation in the sum of $\mathrm{NO}_{2}{ }^{-}$and $\mathrm{NO}_{3}{ }^{-}$was explained primarily by the variation in CD163 (96\%); with the addition of TNF- $\alpha$, it was a total of $99 \%$.

At ultrastructural observation, macrophages were present in the interstitial space close to capillaries in the muscle sections of the six patients that were examined for this purpose. An example is shown in Fig. 8.

\section{Discussion}

In the present report, increased levels of iNOS and nitrotyrosine were found in skeletal muscle of type 2 diabetic patients, indicating a high production of $\mathrm{NO}$. $\mathrm{NO}_{2}{ }^{-}$and $\mathrm{NO}_{3}{ }^{-}$were also increased, but not to the same extent as nitrotyrosine and iNOS. This suggests that a high proportion of $\mathrm{NO}$ reacted with superoxide to produce peroxynitrite, finally resulting in nitrotyrosine formation.

In a skeletal muscle sample, there are muscle fibres, connective tissue, microvessels and nerve fibres. eNOS and iNOS have been demonstrated to be present in endothelial cells and muscle fibres; therefore, we cannot rule out that iNOS may be activated in muscle and/or endothelial cells. However, the presence of macrophages shown by the increased levels of CD163, which is a good marker for these cells (Malm et al. 2000), together with the finding of macrophages in the biopsies of all six patients that were examined, provides evidence for the involvement of macrophages in muscle alteration of type 2 diabetic subjects. Furthermore, the increased levels of CD154 and TNF- $\alpha$ indicate that an inflammatory process is involved in iNOS activation and NO production (van der Veen 2001).

Pickup et al. (2000) found increased circulating levels of IL- 6 and TNF- $\alpha$ in type 2 diabetic subjects, but these cytokines were decreased in cultured diabetic blood. It is possible that the migration of white cells to tissues such as skeletal muscle is important for cytokine production.

In the present results, the variation in levels of the $\mathrm{NO}$ products $\mathrm{NO}_{2}{ }^{-}$and $\mathrm{NO}_{3}{ }^{-}$was explained in the multipleregression analysis by the variation in CD163 (96\%), and adding TNF- $\alpha$ explained $99 \%$ of the variation. This strongly suggests a role for macrophages in activation of NO production. CD163 is a highly expressed macrophage membrane protein belonging to the scavenger receptor cysteine-rich (SRCR) domain family (Graversen et al. 2002). It has been demonstrated that iNOS expression in skeletal muscle in vivo and in vitro requires IL-1 $\beta$ and IFN $\gamma$ to induce NFKB activation (crucial for iNOS transcription) (Adams et al. 2002). The increase in iNOS expression required more than two signals related to an immune inflammatory reaction. Activated $\mathrm{T}$ cells produce IFN- $\gamma$, which in turn increases macrophage IL-1 $\beta$, IL-6 and, as a consequence, TNF- $\alpha$ (Adams et al. 2002). We detected that CD154 was present in the muscle homogenates of the type 2 diabetic patients, compared to undetectable levels in control subjects. Other investigators reported that soluble CD154 (CD40L) is elevated in plasma of type 1 and type 2 diabetic patients (Varo et al. 2003) and in serum of type 2 diabetic patients with coronary artery disease (Marx et al. 2003). Thus, one may assume that an inflammatory reaction observed in the diabetic muscle involves $\mathrm{T}$-cell and macrophage activation, and specifically inflammatory cytokines that enhance NO, superoxide, peroxynitrite and consequently nitrotyrosine generation.

It has been recently reported that obese tissue is characterised by macrophage infiltration (Weisberg et al. 2003, Xu et al. 2003). In the present work, muscle samples were macroscopically free of fat, and no adipocytes were seen at ultrastructural analysis. Although four patients and one control were over 27 , neither TNF- $\alpha$ nor CD163 muscle levels were related to BMI; however, this does not exclude that macrophage presence in muscle may have some relationship to intramuscular lipids.

\section{The possible link between hyperglycaemia and inflammation}

CD163 has been identified as the endocytic receptor binding haemoglobin in complex with the plasma protein haptoglobin (Graversen et al. 2002). It is conceivable that 


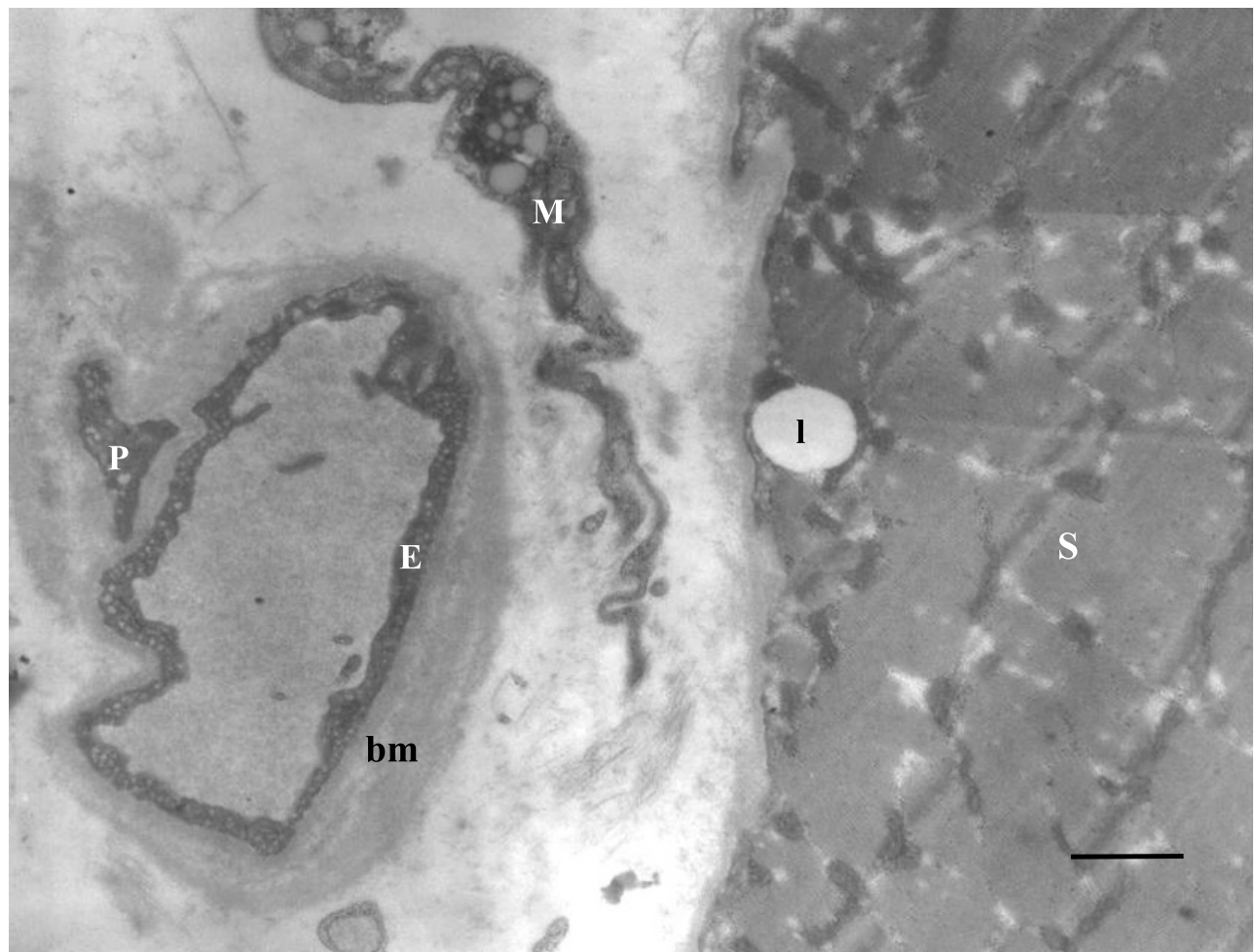

Figure 8 Transmission electron microscope oblique section of vastus lateralis part of quadriceps muscle of a type 2 diabetic patient. Bar $=1 \mu \mathrm{m}$. Section of a muscle fibre (right): Sarcomere (S). Empty space of a lipid droplet (I). Cell in the centre of the section is a macrophage (M). Capillary (left): endothelial cell (E), thick basement membrane $(\mathrm{bm})$ and pericyte $(\mathrm{P})$.

glycated haemoglobin, and maybe other advanced glycation end products (AGEs), would trigger macrophage attraction into tissues. In the present work, a correlation was found between glycated haemoglobin and CD163, supporting this possibility.

\section{Origin of superoxide}

AGEs may cause pathological changes by generation of reactive oxygen species, probably acting through receptors for AGE (Yan et al. 1994, Wautier et al. 2001); therefore, activation of iNOS will coincide with production of $\mathrm{O}_{2}^{-}$, leading to peroxynitrite production. The addition of glycated human oxyhaemoglobin to normal omental microvessels impaired NO-mediated responses by a mechanism involving superoxide anions (Vallejo et al. 2000). In addition, reaction products of iNOS, AGEs and $\mathrm{NF \kappa B}$ have been found in aortic endothelial and smooth muscle cells of streptozotocin diabetic Mongolian gerbils (Nishigaki et al. 1999), and normalising levels of mitochondrial reactive oxygen species, which were increased by hyperglycaemia in cultured bovine aortic endothelial cells, prevented glucose-induced activation of protein kinase $\mathrm{C}$, formation of AGEs, sorbitol accumulation and NFKB activation (Nishikawa et al. 2000).
In the present results, the variation in nitrotyrosine could be predicted mainly by the changes in glycated haemoglobin, indicating that superoxide formed by the action of AGEs would eventually lead to the formation of peroxinitrite and tyrosine nitration. It is not known whether NO-derived nitrogen species can nitrate tyrosine residues of the insulin receptor and give rise to insulin resistance, although this is theoretically possible (Perreault \& Marette 2001). If this did occur, a vicious circle would perpetuate hyperglycaemia and insulin resistance.

Nitrotyrosine has been found in plasma of diabetic patients, although it was undetectable in plasma of control subjects (Ceriello et al. 2001). However, in the present study, nitrotyrosine was found in skeletal muscle of normal subjects but in a quantity fourfold lower than in diabetic patients.

In conclusion, iNOS is increased in skeletal muscle samples of type 2 diabetic patients. Although this enzyme may be induced in muscle fibres and endothelial cells, the presence of macrophages and the increased levels of TNF- $\alpha$ and CD154 are evidence of an inflammatory process with macrophage and $\mathrm{T}$-cell activation. The moderate increase of the $\mathrm{NO}$ products $\mathrm{NO}_{2}{ }^{-}$and $\mathrm{NO}_{3}{ }^{-}$, contrasting with the markedly augmented levels of nitrotyrosine, indicates that $\mathrm{NO}$ reacted with $\mathrm{O}_{2}^{-}$to produce 
$\mathrm{ONOO}^{-}$, which finally nitrated tyrosine residues. The superoxide ion necessary to react with $\mathrm{NO}$ for the production of $\mathrm{ONOO}^{-}$may have been generated in relation to AGE formation, as suggested by the correlation between glycated haemoglobin and nitrotyrosine.

\section{Acknowledgements}

This study was supported by grants from the Consejo de Desarrollo Científico y Humanístico of the Central University of Venezuela (No. 09·33·4367-1999), and from FONACIT S1 (2000000149). We thank Lic. Lourdes Suárez for statistical advice.

\section{References}

Adams W, Nehrhoff B, Späte U, Linke A, Schulze PC, Baur A, Gielen S, Hambrecht R \& Schuler G 2002 Induction of iNOS expression in skeletal muscle by IL- $1 \beta$ and NFKB activation: an in vitro and in vivo study. Cardiovascular Research 54 95-104.

Beck K-F, Eberhardt W, Frank S, Huwiler A, Messmer UK, Mühl H \& Pfeilschifter J 1999 Inducible NO synthase: role in cellular signaling. Journal of Experimental Biology 202 645-653.

Beckman JS \& Koppenol WH 1996 Nitric oxide, superoxide, and peroxynitrite: the good, the bad, and the ugly. American Journal of Physiology 271 C1424-C1427.

Bedard S, Marcotte B \& Marette A 1998 Insulin inhibits inducible nitric oxide synthase in skeletal muscle cells. Diabetologia $\mathbf{4 1}$ $1523-1527$.

Ceriello A, Mercuri F, Quagliaro L, Assaloni R, Motz E, Tonutti L \& Taboga C 2001 Detection of nitrotyrosine in the diabetic plasma: evidence of oxidative stress. Diabetologia 44 834-838.

Cosentino F, Hishikawa K, Katusic Z \& Lüscher TF 1997 High glucose increases nitric oxide synthase expression and superoxide anion generation in human aortic endothelial cells. Circulation 96 25-28.

Di Mario U \& Pugliese G 2001 15th Golgi lecture: from hyperglycaemia to the dysregulation of vascular remodelling in diabetes. Diabetologia 44 674-692.

Graversen JH, Madsen M \& Moestrup SK 2002 CD163: a signal receptor scavenging haptoglobin-hemoglobin complexes from plasma. International Journal of Biochemistry and Cell Biology 34 309-314.

Green LC, Wagner DA, Glogowski J, Skipper DL, Whisnok JS \& Tannenbaum SR 1982 Analysis of nitrate, nitrite and 15n-nitrate in biological fluids. Analytical Biochemistry 126 131-138.

Malm C, Nyberg P, Engström M, Sjódin B, Lenkei R, Ekblom B \& Lundberg I 2000 Immunological changes in human skeletal muscle and blood after eccentric exercise and multiple biopsies. Journal of Physiology 529 243-262.

Marette A 2002 Mediators of cytokine-induced insulin resistance in obesity and other inflammatory settings. Current Opinion in Clinical Nutrition and Metabolic Care 5 377-383.

Marx N, Imhof A, Froehlich J, Siam L, Ittner J, Wierse G, Schmidt A, Maerz W, Hombach V \& Koening W 2003 Effect of rosiglitazone treatment on soluble CD $40 \mathrm{~L}$ in patients with type 2 diabetes and coronary artery disease. Circulation 107 1954-1957.

Moncada S, Palmer RMJ \& Higgs EA 1991 Nitric oxide: physiology, pathophysiology, and pharmacology. Pharmacological Reviews $\mathbf{4 3}$ 109-142.

Moshage H, Kok B, Huizenga JR \& Jansen PL. 1995 Nitrite and nitrate determinations in plasma: a critical evaluation. Clinical Chemistry 4 892-896.
Nishigaki R, Guo F, Onda M, Yamada N, Yokoyama M, Naito Z, Asano G, ShimizuSuganuma M, Shichinohe K \& Aramaki T 1999 Ultrastructural changes and immunohistochemical localization of nitric oxide synthase, advanced glycation end products and NFKB in aorta of streptozotocin treated Mongolian gerbils. Nippon Ika Daigaku Zasshi 66 166-175.

Nishikawa T, Edelstein D, Du XL, Yamagushi S-I, Matsumura T, Kaneda Y, Yorek MA, Beebe D, Oates P, Hammes H-P et al. 2000 Normalizing mitochondrial superoxide production blocks three pathways of hyperglycemic damage. Nature 404 787-790.

Perreault M \& Marette A 2001 Targeted disruption of inducible nitric oxide synthase protects against obesity-linked insulin resistance in muscle. Nature Medicine 7 1138-1143.

Pickup JC, Chusney GD, Thomas SM \& Burt D 2000 Plasma interlukin-6, tumour necrosis factor $\alpha$ and blood cytokine production in type 2 diabetes. Life Sciences 67 291-300.

Pieper GM 1998 Review of alterations in endothelial nitric oxide production in diabetes. Protective role of arginine on endothelial dysfunction. Hypertension 31 1047-1060.

Schmidt HHHW, Hofmann H, Schindler U, Shutenko ZS, Cunningham DD \& Feelisch M. 1996 No .NO from NO synthase. PNAS 93 14492-14497.

Stamler JS \& Meissner G 2001 Physiology of nitric oxide in skeletal muscle. Physiological Reviews 81 209-237.

Sulahian TH, Hintz KA, Wardnell K \& Guyre PM 2001 Development of an ELISA to measure soluble CD163 in biological fluids. Journal of Immunological Methods 252 25-31.

Vallejo S, Angulo J, Peiró C, Nevado J, Sánchez-Ferrer A, Petidier R, Sánchez-Ferrer CF \& Rodríguez-Mañas L 2000 High glycated oxyhaemoglobin impairs nitric oxide relaxations in human mesenteric microvessels. Diabetologia 43 83-90.

van der Veen RC 2001 Nitric oxide and T helper cell immunity. International Immunopharmacology 1 1491-1500.

van Kooten C \& Banchereau J 2000 CD40-CD40 ligand. Journal of Leukocyte Biology 67 2-17.

Varo N, Vicent D, Libby P, Nuzzo R, Calle-Pascual AL, Bernal MR, Fernández-Cruz A, Veves A, Jarolim P, Varo JJ et al. 2003 Elevated plasma levels of the atherogenic mediator soluble CD40 ligand in diabetic patients. A novel target of thiazolidinediones. Circulation 107 2664-2669.

Wang MX, Murrel DF, Szabo C, Warren RF, Sarris M \& Murrell GA 2001 Nitric oxide in skeletal muscle: inhibition of nitric oxide synthase inhibits walking speed in rats. Nitric Oxide 5 219-232.

Wang W, Wang S, Yan L, Madara P, Cintron ADP, Wesley RA \& Danner RL 2000 Superoxide production and reactive oxygen species. Signaling by endothelial nitric-oxide synthase. Journal of Biological Chemistry 275 16899-16903.

Wautier M-P, Chappey O, Corda S, Stern DM, Schmidt AM \& Wautier J-L 2001 Activation of NADPH oxidase by AGE links oxidant stress to altered gene expression via RAGE. American Journal of Physiology 280 E685-E694.

Weisberg SP, McCann D, Desai M, Rosenbaum M, Leibel RL \& Ferrante AW Jr 2003 Obesity is associated with macrophage accumulation in adipose tissue. Journal of Clinical Investigation 112 1796-1808.

Xu H, Barnes GT, Yang Q, Tan G, Yang D, Chou CJ, Sole J, Nichols A, Ross JS, Tartaglia LA et al. 2003 Chonic inflammation in fat plays a crucial role in the development of obesity-related insulin resistance. Journal of Clinical Investigation 112 1821-1830.

Yan SD, Schmidt AM, Anderson GM, Zhang J, Brett J, Zou YS, Pinsky D \& Stern D 1994 Enhanced cellular oxidant stress by the interaction of advanced glycation end products with their receptor/binding proteins. Journal of Biological Chemistry 269 9889-9897.

Ye YZ, Strog M, Huang Z-Q \& Beckman JS 1996 Antibodies that recognize nitrotyrosine. Methods in Enzymology 269 201-209.

Zou M-H, Shi C \& Cohen RA 2002 High glucose via peroxynitrite causes tyrosine nitration and inactivation of prostacyclin synthase 
that is associated with thromboxane/prostaglandin H2 receptor-mediated apoptosis and adhesion molecule expression in cultured human aortic endothelial cells. Diabetes 51 198-203.
Received in final form 10 February 2004

Accepted 18 February 2004 